\title{
The constructions of early childhood practitioners' literacy needs on an in-service Bachelor of Education course
}

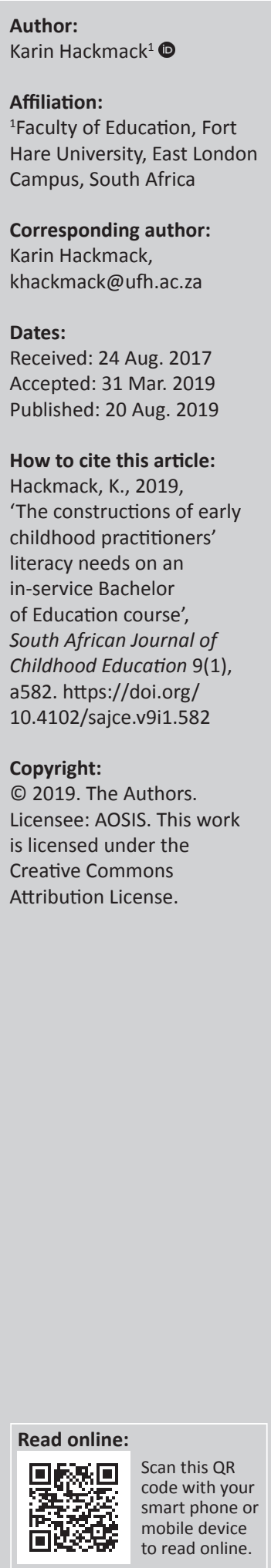

Background: Academic literacy(ies) is a major determining qualifier for success in a university qualification. Academic literacy(ies), in this study, are seen as social practices or discourses that occur within specific academic disciplines. Students therefore needed to 'learn' the academic literacy(ies) discourse of the faculty.

Aim: This study investigated the way lecturers and the course facilitators understood literacies and their students' literacy demands.

Setting: The early childhood practitioners were attempting to obtain a B.Ed degree on a piloted degree career path at a university.

Methods: Data were collected from individual and focus group interviews, one assessment task, and one assessment report from each respective course. Two lecturers and two course facilitators participated in the individual interviews, and three lecturers and three course facilitators participated in the focus group interviews.

Results: The study revealed that the course facilitators' and lecturers' understanding of literacies was not cognisant of literacy as a set of social practices, nor of the enormous changes students needed to make at the level of identity to progress in their academic careers.

Conclusion: The findings from the study showed a disjuncture between the understanding of the meaning of academic literacies by course facilitators and lecturers. A focused and cohesive discussion on academic literacy needs to occur in order to facilitator the practitioners' progress.

Keywords: academic literacies; discourses; early childhood; practitioners; ideological model of literacy; autonomous model of literacy.

\section{Introduction}

This article deals with the concept of academic literacy(ies) and the perceptions of the course facilitators about academic literacy(ies) and consequently their students' literacy needs. The focus on academic literacy was because of the fact that literacy continues to be one of the determining factors of students' success at university. A focus on academic literacy(ies) is required as the number of students enrolled at universities has grown considerably (Calderon 2012). This is true in South Africa, where after 1994, access was opened to all potential students (Butler \& Van Dyk 2004:1; Council of Higher Education [CHE] 2016), and the National Qualifications Framework (NQF) provided access and redress for many students. However, access was not necessarily equated with success as universities have a low throughput rate (CHE 2016; McKenna 2012). A 50\% completion rate was achieved by students who enrolled at universities in 2008 (CHE 2016). As academic literacy(ies) plays such a pivotal role in the success of the student, it is important to understand what is meant by the term academic literacy(ies).

\section{Academic literacy(ies)}

The concept of academic literacy has a number of interpretations. However, this study uses the concept of academic literacies (plural) as outlined (Street in Baker, Clay \& Fox 1996):

Academic writing is not a single thing but an aggregation of literacy practices that make, and are made, by the epistemologies and practices (including the use of power) of specific disciplines and other institutional formations; that it mediates identity struggles; that it is largely transparent to instructors socialised in a discipline, assumed; that technical solutions such as study skills do not get at the problem (p. 118). 
This study acknowledges that the term 'academic literacy' in the singular hides the complexity of the term and restricts literacy to a singular set of practices (Henderson \& Hirst 2007; Lea \& Street 1998). The perception of literacies as a set of social practices shifts the focus from the deficit discourse of placing the blame squarely on the shoulders of the students.

However, the study also takes cognisance of the work done by Richards and Pilcher (2016) and Lillis and Scott (2007), who argue that the term 'academic literacies' is inadequate. Lillis and Scott (2007) state that neither the term 'academic literacy' in the singular or in the plural is adequate. Instead they propose that it is viewed 'as a field of enquiry with a specific epistemological and an ideological stance' (Lillis \& Scott 2007:5). As neither the singular nor the plural adequately describes the complexity of academic literacy, the term academic literacy(ies) is used in this study.

\section{The importance of academic literacy(ies)}

Academic literacy is seen as the common understanding of the rules and conventions that most academics share and the means that will be used to judge the students' competence (Ballard \& Clanchy 1988). Student success therefore depends on them following the conventions and cracking the code of reading and writing that is prized by the university (Gee 2000).

Students need to be provided with access to the privileged academic literacies of the university. To succeed, the students need to take on the 'ways of being and doing' of the course and the university. In other words, the students need to be enculturated into the Discourses (deliberately capitalised) (Gee 1996:146; Northedge 2003:19) associated with the course. These Discourses cannot be overtly taught in a set of introductory lectures (Boughey 2000:281), but will be developed throughout the students' academic career. The Discourses need to be embedded into the course content (Neil \& Shashi 2016). The lecturers need to develop the students' academic literacy, until 'ways of speaking, acting, thinking, feeling and valuing common to that discourse become natural to them' (Boughey 2000:281; McKenna 2004:279). If the Discourses are not made overt to the students, they will not succeed academically and they will find it difficult to participate in the academic Discourses of their disciplines (Crook 2005).

This study was conducted using the third cohort of BEd students. The students had progressed through various Early Childhood Development (ECD) courses, which should have ultimately prepared them for the BEd. This study focuses on how the university lecturers and the Institute course facilitators understood literacy(ies) and how they, thus, perceived their students' literacies and literacy demands. In addition, the way in which academic literacy(ies) was conceptualised by course facilitators and lecturers would impact the way they developed and designed course content and assessment tasks to meet the black majority of the student body.
The students enrolled on the BEd ECD career path were from different socio-economic backgrounds and are termed 'historically disadvantaged' students (Butler \& Van 2004:1). These students are also first-generation higher education students. However, Higher Education Institutions (HEI) academic literacies are mainly middle class Discoures, which are different from their home-based Discourse. Heath's (1983:2) study on language patterns and effects within community, home and school setting in two working class communities and one middle class community showed that the language skills and values that the school valued were those of the middle class community. The home context therefore would not necessarily prepare students for the more powerful and valued literacies of the universities. Northedge (2003) notes that a difference exists between work-based discourse and academic discourses.

Scollon and Scollon's (1981) research supported the concept of home literacies being different from school and that it is usually the literacies that the children acquire from home rather than the school that prepare children for HEI. This is relevant to my study as the participants are mostly working class, and live in communities where different sets of literacy practices exist to those that are dominant in schools and universities. This means that whatever practices students might encounter on the courses or in schools are not affirmed in their home contexts. The concept that the knowledge at university is different from that of the school resonates with Bernstein's (1999) theory of different types of knowledge, which he terms 'discourses'. Bernstein (1999) distinguishes between horizontal discourse and vertical discourse. The horizontal discourse or common sense or 'profane' knowledge is the kind of knowledge that is acquired and used in the home and local community.

In addition, McKenna (2004) found in her research that lecturers tended to focus on surface grammar errors. This is what Christie (1985) identifies as a model of language as an instrument of communication, in contrast with a model of language as a resource. The 'model of language as an instrument of communication' views language as a mere conduit, carrying the meaning and message (Christie 1985). This model of language sees thought to be independent of language, which is merely a channel for communicating 'pre-made' thoughts to others (Christie 1985).

Christie contrasts this with a 'model of language as a resource', which sees language use as involving choices that are informed by context. The context, in turn, is informed by belief systems and values. Academic literacy draws on beliefs and values relating to what can count as knowledge, and how it can be acquired. These beliefs, then, inform language choices. For example, the belief that objectivity is important in knowledge creation would lead to the use of the passive rather than the active in some academic texts.

Closely linked to model of language as an instrument of communication is Christie's (1993) identification of what she 
terms the 'Received Tradition of English Teaching', which 'calls for the remedying of grammatical problems, as if a conscious knowledge of the surface rules of language is what the students are lacking', and assumes that if these instructions were made overt to the students the problem would disappear (McKenna 2004:282). As Christie (1995) points out, grammar teaching can be related to a form of social control - control that ultimately seeks to deny access to powerful ways of 'meaning-making' by forcing students to focus on the details of language use, which they actually did not control, at the expense of more meaning-related concerns.

To understand the unique nature of the career path and the various qualifications, the history of ECD and teacher training is required.

\section{Historical background}

In South Africa, ECD pertains to the education of any child between the ages 0 and 9 years (Department of Education 1995). This definition sees ECD straddling both the pre-school and formal schooling sectors. Prior to 1995, the in-service training of ECD practitioners had little or no legislation controlling and setting standards for ECD courses. ECD training was mainly carried out by non-profit organisations with a few Further Education and Technical and Vocational and Educational Colleges (TVET) also offering courses. This resulted in a number of practitioners holding 'historic qualifications' that were issued on an ad hoc basis with no consistency regarding the content, length and quality of the courses (Department of Education [DE]) 2001, (Department of Higher Education and Training [DHET]) and plethora of unregulated qualifications in the South African education system was one of the reasons for the development of the NQF, in 1995.

The NQF outlined and agreed upon standards and qualifications and amalgamated the ECD training into one integrated single national system (SAQA 2007). The NQF also outlined the various qualifications and allocated educational levels (see Figure 1). The NQF made provision for a (limited) career path for students as they progressed through qualification levels (SAQA 2007) (up to a level 5 qualification). This resulted in the Education and Training Development Practices Sector Education Training Authority (ETDP SETA) developing Unit Standards-based courses for ECD training at levels 1-5. Exit-level outcomes were developed for each of the levels. The ECD level 5 comprises a large credit-bearing academic literacy fundamental course. This is significant as, according to the NQF, a level 5 was at the time equivalent to the first year of university. The formulisation of ECD training provided practitioners with the opportunity to obtain formal ETDP SETA qualifications at all levels, after successfully demonstrating achievement of the exit-level outcomes. A level 4 and/or level 5 whole qualification permitted students to apply for a Grade $\mathrm{R}$ post within the formal schooling structure.

\begin{tabular}{|c|c|c|c|}
\hline \multicolumn{4}{|c|}{ New and old teacher education structure } \\
\hline Level & $\begin{array}{l}\text { New teacher } \\
\text { qualification } 2015\end{array}$ & & NQF (1995) \\
\hline 10 & $\begin{array}{l}\text { Doctor of Education } \\
\text { Degree }\end{array}$ & & \\
\hline 9 & $\begin{array}{l}\text { Masters of Education } \\
\text { Degree }\end{array}$ & & \\
\hline 8 & $\begin{array}{l}\text { Bachelor of Honours } \\
\text { Degree in Education }\end{array}$ & $\begin{array}{l}\text { Post-Graduate } \\
\text { Diploma in Education }\end{array}$ & $\begin{array}{l}\text { Master of Education } \\
\text { Degree }\end{array}$ \\
\hline 7 & $\begin{array}{l}\text { Bachelor of Education } \\
\text { Degree }\end{array}$ & $\begin{array}{l}\text { Advanced Diploma in } \\
\text { Education }\end{array}$ & $\begin{array}{l}\text { Bachelor of Honours } \\
\text { Degree in Education }\end{array}$ \\
\hline 6 & & $\begin{array}{l}\text { Grade R Diploma } \\
\text { ( } 360 \text { credits) } \\
\text { Further Diploma in } \\
\text { Education: Early } \\
\text { Childhood } \\
\text { Development } \\
\text { (TVET Colleges) ( } 240 \\
\text { credits) }\end{array}$ & $\begin{array}{l}\text { Bachelor of Education } \\
\text { Degree and Advanced } \\
\text { Certificate in Education } \\
\text { (ACE) } \\
\text { National N Diploma: } \\
\text { Educare (TVET Colleges) } \\
\text { Further Diploma in } \\
\text { Education: Early } \\
\text { Childhood } \\
\text { Development (TVET } \\
\text { Colleges) ( } 240 \text { credits) }\end{array}$ \\
\hline 5 & & & $\begin{array}{l}\text { National Diploma in } \\
\text { ECD ( } 240 \text { credits) and }\end{array}$ \\
\hline 4 & & & $\begin{array}{l}\text { Level } 4 \text { ECD programme } \\
\text { - equivalent to a school } \\
\text { leaving certificate }\end{array}$ \\
\hline
\end{tabular}

Source: Adapted from Irvine, M., 2009, 'An in-service ECD career path at Rhodes University, South Africa from 'school leaving' certificate to post graduate level', paper presented at the 4th African International ECD conference, Dakar, Senegal, November 2009

NQF, National Qualifications Framework; TVET, Technical and Vocational and Educational Colleges.

FIGURE 1: The old and new teacher qualification structure in South Africa.

In 2011, the Department of Higher Education and Training developed a new framework and guidelines for teacher education. The new teacher qualification legislation set out the Minimum Requirements for Teacher Education Qualification (MRTEQ) (DHET 2011) and altered the teacher qualification landscape. Minimum Requirements for Teacher Education Qualification was revised in 2015 to take into consideration the new Higher Education Qualifications Framework (HEQF) (DHET 2015). Figure 1 illustrates the framework for formal Teacher Education Qualifications and ECD prior to and after 2015.

\section{Challenges of the career pathing for practitioners}

After the completion of the ECD level 5 Diploma, options were limited for practitioners, despite the implementation of the NQF. The students were unable to enrol on the now defunct Advanced Certificate in Education (ACE), as the course focused on in-service teachers upgrading and practitioners did not meet the entry requirements. The only degree options available were to either enrol on a full-time 4-year BEd course, offered by a Faculty of Education (at a university), or a full-time distance education BEd (through a distance education university). Neither of these options was financially viable for the students.

The students were mostly mature in-service students (the majority were female), studying part-time and working in ECD centres or at a Grade R at a school. Practitioners teaching in a Grade R class are employed by the Department 
of Basic Education (DBE), but are regarded as 'underqualified' and therefore receive a much lower salary than a 'qualified' teacher. In many instances, they were the sole breadwinner and had the added responsibility of supporting and raising their families. The majority of students could therefore not afford tuition fees.

The introduction of MRTEQ (DHET 2011) provided a third option for practitioners, namely, that of a Diploma in Grade $\mathrm{R}$ teaching. The Grade R Diploma would provide them with the credit equivalent of the first year of a BEd. The practitioners would still need to complete three more full years of study to obtain a BEd degree.

These challenges are what galvanised the ECD practitioners to approach the Faculty of Education to request assistance. The Faculty of Education, in conjunction with the Institute, established a pilot career path for ECD practitioners in 2008.

The Department of Higher Education (2017) has recently published the 'Minimum Requirements for Programmes Leading to Qualifications in Higher Education for Early Childhood Development Educators'. This Act specifically deals with the qualification of educators from birth to 4 years. This has provided another option for students as it outlines a comprehensive career path for ECD practitioners. This career path permits students to be granted recognition of prior learning for their ECD level 5 qualifications. The career path will enable practitioners to obtain a BEd degree, honours degree and a masters and doctorate qualifications in Early Childhood Care and Education (ECCE). The policy defines ECD as encompassing $0-4$ years, so it makes a clear distinction and limits students' mobility in terms of moving into the formal schooling sector.

\section{The career path established by the Faculty of Education}

The Institute had been offering accredited qualifications at levels 4 and 5 for ECD practitioners, for a number of years. The lack of access to suitable further educational opportunities for the practitioners resulted in the establishment of the more comprehensive 'career path'.

When the 'career path' for ECD practitioners was established in 2008 (Irvine 2009), practitioners were able to enrol for programmes where they could acquire an ECD qualification at NQF level 4 (the equivalent of a school leavers' certificate, see Figure 1), a National Diploma in Early Childhood Education (ND ECD at NQF level 5), and a Bachelor of Education Foundation Phase (BEd FP) at NQF level 6 (now regarded as NQF level 7). After the successful completion of the ND ECD (situated at level 5), students were given an opportunity to apply for the in-service BEd (birth to 9 years) offered by the Faculty of Education in conjunction with the Institute (see Figure 2). The Institute was responsible for housing the BEd programme: the logistics and the oversight of the BEd. The BEd programme was specifically designed so that the students could have face-to-face lectures outside of school hours.

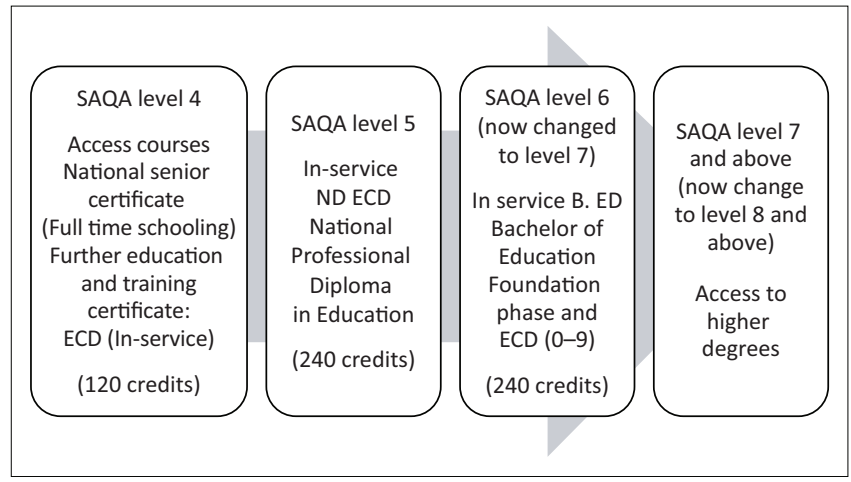

Source: SAQA, South African Qualification Authority.

FIGURE 2: The Institute's career path.

The Institute was cognisant of the fact that while financial support had been provided to the students this did not necessarily mean students would succeed academically (Du Plessis \& Gerber 2012:1; Morrow 2009). The Institute needed to assist students to succeed (Engstrom \& Tinto 2008) especially with the academic literacy requirements of the various courses, as academic literacy is the literacy that is most valued at HEIs (Boughey 2002; Henderson \& Hirst 2006) and consequently has a high status.

\section{Theoretical framework}

This study was framed by Gee's (2008:154) definition of Discourse and Street's (1984) autonomous and ideological theories of literacy.

Gee (2008) defines Discourse (capital D) as:

... [C]omposed of distinctive ways of speaking/listening and often, too, writing/reading coupled with distinctive ways of acting, interacting, valuing, feeling, dressing, thinking, believing, with other people and with various objects, tools, and technologies, so as to enact specific socially recognizable identities engaged in specific socially recognized activities. ( $p$. 154, original emphasis)

A Discourse, then, is a socially constructed role into which we are socialised over time (Gee 1990). Gee (1990) explains this process of socialisation by distinguishing between primary and secondary Discourses.

The primary Discourse is seen as the initial socialisation that occurs at home. Literacy is defined as the mastery of a Discourse and all individuals are literate in their primary Discourse and are therefore able to demonstrate their membership of the home community. The primary Discourse is used during casual social interactions, and becomes the foundation on which to build further Discourses, acquired later in life. Gee $(2002,2008)$ refers to these Discourses as secondary Discourses. They are the Discourses required by various, 'non-home based social institutions ... these may be used' in academic courses, community group and so forth (Gee 2008). The practitioners in this study would need to use their secondary Discourse when they were studying on the various ECD courses. The secondary Discourse will be more challenging as the students would not have much or any experience of the Discourse, even at school. 
Although the study on which this article is based relied on Gee's concept of discourse (lower case d) and Discourse (upper case D), it was also cognisant of Street's (1984) 'autonomous model of literacy', which is contrasted with the 'ideological model'. The autonomous model sees literacy as being culturally free (Street 1984:29) and as a set of normative technical skills that are detached from the social context in which they are used. Within this model, language is also seen as a set of technical skills that can be taught through drill and repetition (Street 1984). This also resonates with Freire's (1968) analogy of teacher depositing these knowledge and skills into the students and having them memorise and repeat them.

In contrast, the ideological model perceives literacy to be a set of social practices, and not a set of cognitive skills, and emphasises the social context of literacies. Street (2006:78) considers the ideological model to be a much more culturally sensitive view of literacy practices, as they vary from culture to culture. Street (2006) believes that reading and writing practices are dependent on context and the way in which people approach language and writing is tied up with their beliefs, identity and being. This concept is echoed by Boughey (2002), who points out that the way people get meaning from print or writing is dependent on the way they see themselves, the texts and the value they place on text in their everyday lives. Literacy is, therefore, not neutral and value-free, but has ideological underpinnings (Boughey 2002) and consequently we cannot separate literacy from the people who use it, and the institution in which it is used. This moves from a deficit model of literacies to paying attention to the context, purpose and practice in which language is used (Barton et al.2007:17).

The theoretical framing of literacy and of what it means to be a student at a university, outlined above, identifies the role that can be played by lecturers or course facilitators in the processes of acculturation into, following Gee, the Discourses and, following Street, the literacies privileged by the university. To do this, the course facilitators and lecturers need to understand literacies for themselves, understand the students' existing literacies and demands and use this information to inform their teaching. It is not enough for the course facilitators and lecturers to have an in-depth understanding of literacy practices of the university; they also need to understand the diverse literacy practices that the students bring to their study (Lea \& Street 1998). This is particularly true for students without a family history of enrolling for qualifications outside of schooling. This is applicable for the in-service students enrolling for this particular career path.

Academic Discourses (in which the highly prized reading and writing practices of the university are located) are secondary Discourses. All students, therefore, who gain access into university, need to acquire the Discourse (the ways of doing and being, etc.) of the university. However, the primary Discourses of some social groups are closer to elevated secondary Discourses of the university. This means that some individuals, usually those from middle class homes with educated parents, have an advantage over others. Bourdieu (1991:502) refers to this as linguistic capital. This had implications for this study, as the students participating in the study, because of apartheid, were structured into working class positions in homes where education had been denied. In many instances, the students on the course are the first generation to finish their schooling, let alone attend post-school courses, or obtain an undergraduate degree.

The rules of Discourses are rarely made explicit (Gee 1996), and this is exacerbated by the fact that, in the academy, Discourses are discipline specific. What constitutes good academic writing or practice in one discipline may not apply to another discipline or course (Lea \& Street 2000:40). In addition, academic literacy cannot be 'taught'; it can only be acquired through scaffolding, in an apprentice situation (Gee 1990).

\section{Research methodology}

A qualitative research method was used. This research set out to determine the privileged literacy Discourses of the university (critical to success) and the way that the lecturers and course facilitators supported the acquisition of literacies.

\section{Data collection methods and sampling}

The data collection began with three individual interviews; one with a course facilitator teaching on the level 4; one course facilitator teaching the level 5 course and with two lecturers from the BEd programme (one of the BEd lecturers had previously taught on level 5 ECD course). The interviewees were purposively chosen to provide a view of how each level scaffolded the students' literacies at each level of the career path. The individual interviews were followed by a focus group interview. The semi-structured individual and group interviews were conducted at a venue and time convenient for the interviewees.

The focus group interviews were conducted with two course facilitator teaching on the level 4 and one on the level 5 course and with two BEd lecturers. Both the individual and focus group followed a semi-structured interview format.

In addition to the interviews, an analysis was conducted on assessment reports. Course facilitators and lecturers were required to complete assessment reports after each assessment had been completed. The reports were based on student performance and required comments on students' strengths and areas for improvement. Three assessment reports were analysed: one from level 4, one from level 5 and one from the BEd course.

For level 4 and level 5 courses, mandatory assessment reports were written by the course facilitator, after each Unit Standard has been assessed. These completed reports were required by the ETDP SETA. After each batch of academic or practical assignments, the BEd lecturer writes a generalised assessment 
report to the students. Each of the assignment reports had a different format and content, and some of the reports were intended for individual students, while others were general reports intended for the whole class.

\section{Data analysis}

Data collected were in the form of interviews and assessment reports. The transcribed interviews and the assessment reports were analysed following the steps outlined by Giorgi, Fischer and Murray (1975). Firstly, all the transcriptions and documents were read to get an impression of the whole. Then the transcriptions and documents were read with the purpose of finding out the exact transactions that occurred during the interviews. This was followed by the elimination of any redundant information. This meant that only the relevant themes were left. This occurred with the assessment report documents as well. Thereafter, any colloquial language of the participants was translated into the language of science. Finally, common recurring discourses were identified and classified into themes. From the preliminary identification of the broad discourses, subordinate discourses began to emerge.

\section{Trustworthiness}

Trustworthiness means that the investigation findings are reliable and rigorous. In this study, triangulation and member checking (Birt et al. 2016) were used. Yeasmin and Rahman (2012) refer to triangulation as a process of verifying and controlling biases so that research increases in validity by incorporating several viewpoints and methods. This research employed a number of theories to explain the data that were collected, and made use of more than one method to collect data. In this study, member checking took the form of requesting the participants to look at the transcribed interviews for accuracy.

\section{Ethical considerations}

In this research, ethical considerations such as the participant's right to anonymity, informed consent, confidentiality and voluntary participation were explained and adhered to. The participants had the right to withdraw from the study at any stage.

\section{Findings and discussion}

The data analysis saw three major discourses emerging, namely, the autonomous view of literacy; literacy as an ideological process and language as an instrument of communication.

\section{The failing education system is responsible for student's deficit abilities in reading and writing}

When students do not succeed at university, this is often assumed to be because of their own inadequate preparation for university. This deficit framing of the student's learning and abilities tends to ignore and devalue the types of literacies that 'non-traditional' students bring with them
(Carstens 2013) to the courses. It also ignores Street's ideological model of academic literacy(ies). As it places the problem on an external factor such as schooling, this means that no introspection needs to be done by the course facilitators and their role in making the Discourse of the university evident to the students.

One of the course facilitators expressed the idea that students are not adequately prepared at school for reading and writing at university:

'... what I have discovered is that children of now a days are really not writing the way we used to write. In the past although there were things that were not accepted ne, we used to write things that can be read you know by somebody even if it's wrong you can know it's wrong nowadays you can see to it you can't even guess what the person wants to say in the assignment you know those are the difficulties we encounter.' (Participant 3, female, ECD facilitator, 35 years old, Level 4 )

The Discourse of the failure of schools to adequately prepare students was mentioned by the level 4 course facilitator:

'They (students) have a difficult time I have a group of students whose basic language and reading and writing skills are poor. They are almost illiterate and now I have to help them do level 4 fundamentals. It is difficult to me. I don't think they can read and write in Xhosa. I get them to read story books. They are not ready for academic reading and writing.' (Participant 4, female, lecturer, 50 years old, B.Ed)

One course facilitator remarked that the basic comprehension skills required at school do not prepare the students to read, make inferences and critically reflect on what they read, as is required of academic literacy at tertiary level. This respondent's comment seems to indicate a belief in the inability of the present education system to equip students with critical literacy.

The deterioration and continued failure of the education system, which was the reason for students' poor performance, was noted by one of the course facilitators. She believed that, in the past, children who passed standard $6^{1}$ had a higher quality of education than the present-day matriculation. ${ }^{2}$ She noted that 'our education is going down - it's as if it can't be changed ...' (Participant 4, female, course facilitator, 50 years old, B.Ed) The respondent notes that 'it seems as though the teachers in the past, maybe they are better, now we're not doing it correctly.' (Participant 4, lecturer, 50 years old, B.Ed). She voiced the opinion that the teachers are just passing the students because during the next academic year they have to have a new group of students, and did not want to deal with students who had failed. She mentions, 'they (teachers) were just passing the buck.'

This discourse draws on the autonomous model of literacy and literacy is socially embedded, and that both schools and universities are distinct social institutions. Johns (1997) 1.This is the 8 th year of schooling which is presently referred to as Grade 8. 2.Matriculation is the last year of public schooling in South Africa. 
suggests that, at school, the only academic reading that students are exposed to is in textbooks, and that the kind of writing that they do is merely summarising the facts from a text book, which, in essence, is a regurgitation of the text book. This leaves the responsibility of enculturating the students into the Discourse of the university with the course facilitators.

\section{Language is a set of skills that students need to learn}

The most common understanding of literacy ascribed to by the lecturers and the course facilitators was that of the autonomous model of literacy (Street 1984), which sees literacy as a set of acultural, asocial skills focusing on the encoding and decoding of printed text. This focus on what Street (1984) terms the 'technology' of literacy which then leads to the development of an understanding of literacy as a set of neutral skills. Therefore, despite their varied groups, both the facilitators who were teaching mature female students, some of whom had a national senior certificate (the students who had a national senior certificate were hoping to be able to carry onto the $\mathrm{BEd}$ ) and the lecturers teaching mature female students who had completed the ECD level 5 course, were now doing the BEd course had similar perceptions of literacy.

One of the course facilitators, whose students came from one of the remotest and rural areas of all the students, noted:

'... as we do not have time, not enough time to educate everyone to be able to read and write. I think in fact, what I do is to encourage them to go and attend ABET [Adult Basic Education and Training] classes so as to get more education like in the form of reading and writing because these are the skills that they will need more especially when they are teachers obvious that they have to write every now and again.' (Participant 3, female, ECD facilitator, 35 years old, Level 4 )

Her view was that the more the students practised, the more their academic skills would improve and this would impact their understanding of the work covered in the course. One course facilitator, reported that she had 'a group of students whose basic language and reading and writing skills are poor.'

The resounding idea of the skills approach to literacy was also mentioned by another course facilitator who said:

'They need to read a lot. They need to read all the books and the newspaper they come up with so they get used to reading the more they read the more they get knowledge and the more they develop their skills in order to read and write.' (Participant 5, female, lecturer, 58 years old, B.Ed)

These course facilitators felt that if the students' reading improved, then this would improve the students' ability to produce written texts. This was, in particular, a concern for the level 5 ECD course facilitator who commented, 'As you know, reading and writing skills (academic literacy) are extremely important in this course, because it is equivalent to the first years of a degree.' (Participant 2, female, course facilitator, 43 years old, Level 5)
This was further supported by a comment on the assessment reports where a lecturer wrote the following note to the students:

'Writing ... it is hard to do in the beginning. It gets easier the more you do it. It is like sewing or knitting or driving a car. It is not easy to begin. The more you sew, the faster you get at sewing. They more you sew, the more you learn, the better you get at sewing. Writing is not different.' (Participant 4, female, lecture, 50 years old, B.Ed)

While there is no doubt that the ability to produce academic text does improve with practice, this sort of comment takes no account, for example, of the need for students to develop the understanding of the value system that underpins academic text.

A course facilitator reported that she perceived that some of the students on the certificate courses were illiterate. This showed her perception that one was either literate or illiterate and the idea that literacy is merely coding and encoding of print. Just because the students were lacking in the particular literacies does not mean that they would not have demonstrated mastery over other literacies.

\section{The ideological discourse of literacy}

'... they (the students) need to read with confidence they need to read all the books they are given, they need to read at home because that is not happening either they only read when they are at the classes they don't read when they are back at home. And culturally, we as blacks, we don't read we are scared to be seen reading a book in public. I think that hinders them from improving their skills in terms of reading and writing.' (Participant 5, lecturer, 58, B.Ed)

The above quote shows that the course facilitator is cognisant of the cultural and social discourses that emerge from home, but simultaneously she subscribes to reading and writing in the terms of learned skills. Therefore, both the autonomous and the ideological Discourse of literacy are subscribed to simultaneously. The course facilitator was not alone in using both Discourses interchangeably. Two of the lectures interviewed as well as the assignment reports had comments relating to the autonomous and ideological nature of literacy simultaneously.

In particular, one of the lecturers made several references to the autonomous nature of literacy; however, the inconsistency in her Discourse can be seen in her comment on the ideological nature of literacy and her awareness that schooling involved more than teaching 'everyday' understanding of things. Bernstein's (1999) horizontal discourse or common sense or 'profane' knowledge was mentioned during the interviews. For example, the lecturer remarked.

'... the students that have come in ... they can write you know. But it's like their reading they write in everyday way and schooling is not about the everyday ... It's about trying to understanding things in more depth ...' (Participant 2, ECD facilitator, 43, Level 4 \& 5) 
The lecturer's comment also resonates with Gee's (2003) idea that children do not only learn literacy (of various sorts) at school, but in fact children are also acquiring these literacies through experiences in the home, which occurs before and after school. Walton, Bowman and Osman (2015:267) also note that the skills, knowledge, dispositions and values that the students bring to the university 'are valid but not necessary valued by the university.'

The ideological discourse was also expressed in course assignment reports for the BEd. For example, in the following comment the ideological model of literacy is evident.

'You may not understand academic English well. You may not be used to reading a lot. You may not be used to thinking academically in English, which is different from thinking in everyday life English when you are chatting to a friend. So even though you speak English from birth, this is a new English to learn ... So in many ways, you are also a second language speaker!' (Participant 4, female, lecture, 50 years old, B.Ed)

\section{The model of language as an instrument of communication}

Christie's (1985) two models (a model of language as an instrument of communication and a model of language as a resource) were a theme running through the data. Evidence of both a model of language as an instrument of communication and the Received Tradition of English Teaching can be seen in comments made by the facilitators particularly in relation to assessment. One facilitator, for example, notes:

'... you can't even guess what the person wants to say in the assignment - you know those are the difficulties we encounter. And the spelling errors, the grammar even though I am not an English teacher. We notice such things.' (Participant 2, female, ECD facilitator, 43, Level 4 \& 5)

This facilitator went on to say that:

'we can start teaching them (students) this and that in the form of grammar, spelling etc. They (students) need lessons, a few lessons ... to upgrade their level of knowledge because really we are experiencing problems.' (Participant 2, female, ECD facilitator, 43 , Level 4 \& 5)

Assessment criteria were also redolent of the model of language as an instrument of communication and the Received Tradition. For example, assessors look for simple sentences, spelling and grammar errors when marking students' work. While technical accuracy in language use is important in academic literacy, it is still possible for meaning to be conveyed even if the communication is grammatically incorrect. In academic language use, technical accuracy is part of a value system centred on the use of Standard English.

The assessment reports and tasks also echoed the model of language of communication and the Received Tradition of English Teaching. For example, the use of full sentences was a criterion used in relation to many assessment tasks. A level 4 assignment was evaluated against the criterion 'must be written in full sentences with correct grammar.'
Additional comments reflecting this discourse was seen in the level 4 assignment task that had 'spelling and grammar is correct' as one of the assessment criteria for marking the assignment. The assignment task clearly states that the students' assignment task, or essay, 'must be written in full sentences, with correct grammar.'

Similarly, a level 5 assignment assessment criterion was 'meaning of written text clear and simple using full sentences and adequate sentence structure', while the BEd assessment criterion mentioned 'clear effective sentence structure'. In her research, McKenna (2004) found that lecturers and course facilitators tended to focus on surface grammar errors rather than larger structural issues in an assignment, as the surface errors were easy to see and to mark. This seems to be parallel with the criteria required in the assignment tasks in this research. Furthermore, the level 4 and level 5 assignment reports made mention of spelling with comments, such as 'the sentences were poor. They had a lot of spelling mistakes.' The poor spelling in assignments was also noted in a level 5 report, with a comment that students must:

'please proofread your assignment, or give it to a fellow student to read and make comments on, before you submit it. Use the dictionary to look up words that you are not sure about the spelling.' (Participant 2, female, ECD facilitator, 43, Level 4 \& 5)

In South African Higher Education, a wealth of research has been produced in relation to the so-called 'language problem'. All of this research points to students' language development needs far exceeding that of knowledge of grammar and spelling.

\section{Concluding remarks and recommendations}

It is clear from the assessment reports, which formed part of my data that students following this career path designed for them to become qualified educational practitioners struggled with the reading and writing demands of the academy. This is not surprising given the complexity of the literacy demands made on them. Students were required to read types of texts, which they were unlikely to have encountered previously. In addition, they were required to engage with those texts in a critical fashion where 'criticality' involves reading a text with the intent to question and interrogate it, and use other texts and knowledge of the world, to challenge it (Boughey 2013). Given the theory outlined earlier in this article, and most particularly Street's ideological model of literacy, it can be seen that it is highly unlikely that students would have been socialised into the literacy practices associated with such 'criticality'.

Gee's (1990) construct of Discourse also allows us to understand that the 'being' required of students as they travelled the pathway of qualifications was very different to that of their primary Discourses and, probably, to other secondary Discourses to which they had been exposed. Students were being required to take on an entire new 'role', 
which probably conflicted in numerous ways with previous roles they had played in their lives.

In response to what they experienced as students' literacyrelated 'problems', course facilitators and lecturers had little on which to draw other than their common sense and their own experience of language teaching in the form of the 'Received Tradition' and the autonomous model of literacy. However, in many respects, the adoption of the autonomous model of literacy absolves the course facilitator of any responsibility for perceived underachievement or failures by the students because their failure is seen to lie in their inability to master simple encoding and decoding processes.

The recommendation of this study would be for the Institute and the Faculty of Education to focus on the development of course facilitators' understanding of literacy and what this means for their students. Pym (2013:353) suggests that instead of 'fixing' the students and having them adapt to the university, there is a need to focus on the strengths and challenges that the students bring to the university and move away from a 'one size fits all approach'.

Furthermore, a more shared understanding of what is meant by academic literacy practices and requirements for each of the courses should be unpacked to a greater extent so that students can benefit from a continuous scaffolding process that enables them to succeed academically in all the courses and future courses they enrol for.

\section{Acknowledgements Competing interests}

The authors have declared that no competing interests exist.

\section{Authors' contributions}

All authors contributed equally to this work.

\section{Funding information}

This research received no specific grant from any funding agency in the public, commercial or not-for-profit sectors.

\section{Data availability statement}

Data sharing is not applicable to this article as no new data were created or analysed in this study.

\section{Disclaimer}

The views and opinions expressed in this article are those of the authors and do not necessarily reflect the official policy or position of any affiliated agency of the authors.

\section{References}

Ballard, B. \& Clanchy, J., 1988, 'Literacy in the university: An anthropological approach', in G. Taylor (ed.), Literacy by degrees, pp. 7-23, Society for Research into Higher Education and Open University Press, Milton Keynes.

Barton, D., Appleby, Y., Hodge, R., Ivanic, R. \& Trusting, K., 2007, Literacy, lives and learning, Routledge, New York.
Bernstein, B., 1999, 'Vertical and horizontal discourse: An essay', British Journal of Sociology of Education 20(2), 157-173. https://doi.org/10.1080/01425699995380

Birt, L., Scott, S., Cavers, D., Campbell, C. \& Walter, F., 2016, 'Member checking: A tool to enhance trustworthiness or merely a nod to validation?', Qualitative Health Research 26(13), 1802-1811. https://doi.org/10.1177/1049732316654870

Boughey, C., 2000, 'Multiple metaphors in an understanding of academic literacy', Teachers and teaching: Theory and Practice 6(3), 279-290. https://doi.org/ $10.1080 / 713698740$

Boughey, C., 2002, 'Naming students' problems: An analysis of language-related discourses at a South African university', Teaching in Higher Education 7(3) 295-307. https://doi.org/10.1080/13562510220144798

Boughey, C., 2013, 'What are we thinking of? A critical overview of approaches to developing academic literacy in South African higher education', Journal for Language Teaching 47(2), 25-42. https://doi.org/10.4314/jlt.v47i2.2

Bourdieu, P., 1991, Language and symbolic power, transl. G. Raymond \& M. Adamson, J.B. Thompson (ed.), Polity Press and Blackwell, Cambridge, MA.

Butler, H.G. \& Van Dyk, T.J., 2004, 'An academic English language intervention for first year engineering students', South African Journal of Linguistics 22(1\&2), 1-8. https://doi.org/10.2989/16073610409486356

Calderon, A., 2012, 'Massification continues to transform higher education', University World News 2 (237), 82-97.

Carstens, A., 2013, 'Using literacy narratives to scaffold academic literacy in the bachelor of education: A pedagogical framework', Journal for Language Teaching 46(2), 9-25. https://doi.org/10.4314/jlt.v46i2.1

Christie, F., 1985, Language education, Deakin University Press, Victoria.

Christie, F., 1993, "The "received tradition" of English teaching: The decline of the rhetoric and the corruption of grammar', in B. Green (ed.), The insistence of the letter: Literacy studies and curriculum theorizing, pp. 75-106, Falmer Press, London.

Christie, F., 1995, 'Pedagogic discourse in the primary school', Linguistics and Education 7(3), 221-242. https://doi.org/10.1016/0898-5898(95)90024-1

Crook, C., 2005, 'Addressing research at the intersection of academic literacies and new technology', International Journal of Educational Research 43(7-8), 509-518. https://doi.org/10.1016/j.ijer.2006.07.006

Council of Higher Education (CHE), 2016, South African Higher Education Reviewed; Two decades of democracy, viewed 04 October 2018, from https://www.che.ac. $\mathrm{za} /$ sites/default/files/publications/CHE_South $\% 20$ African $\% 20$.

Department of Education, 1995, White paper on education and training, Government Printers, Pretoria.

Department of Education., 2001, National audit of ECD, Government Printers, Pretoria.

Department of Higher Education and Training, 2001, The plan for higher education, Government Printers, Pretoria.

Department of Higher Education and Training, 2011, 'Minimum requirements for teacher education qualification (MRTEQ)', Government Gazette 583 (34467), 1-64.

Department of Higher Education and Training, 2015, 'Minimum requirements for teacher education qualification (MRTEQ)', Government Gazette 583(34467), 1-72.

Department of Higher Education and Training., 2017, 'Minimum requirements for programmes leading to qualifications in higher education for early childhood development educators', Government Gazette 299, (4759).

Du Plessis, L. \& Gerber, D., 2012, 'Academic preparedness of students: An exploratory study', The Journal of Transdisciplinary Research in Southern Africa 8(1), 81-94. https://doi.org/10.4102/td.v8i1.7

Engstrom, C. \& Tinto, V., 2008, 'Access without support is not opportunity', Change: The Magazine of Higher Learning 40(1), 46-50. https://doi.org/10.3200/ The Magazine of

Freire, P., 1968, Pedagogy of the oppressed, Penguin Books, London.

Gee, J.P., 1990, Social linguistics and literacies: Ideology in discourse, Taylor \& Francis, London.

Gee, J.P., 1996, Social linguistics and literacies: Ideology in discourse, Taylor \& Francis, London.

Gee, J., 2000, 'The new literacy studies: From "socially situated" to the work of the social', in D. Barton, M. Hamilton \& R. Ivanic (eds.), Situated literacies: Reading and writing in context, pp. 180-196, Routledge, New York.

Gee, J.P., 2002, Social linguistics and literacies: Ideology in discourses, Routledge Falmer, London.

Gee, J.P., 2003, 'What video games have to teach us about learning and literacy', ACM Computers in Entertainment 1(1), 1-4. https://doi.org/10.1145/950566.950595

Gee, J.P., 2008, Social linguistics and literacies: Ideology in discourses, Routledge, New York.

Gee, J.P., 2013, 'Discourse and "the new literacy studies"', in J.P. Gee \& M. Handford (eds.), The Routledge handbook of discourse analysis, Routledge, New York.

Giorgi, A., Fischer, C. \& Murray, A., (eds.), 1975, Duquesne studies in phenomenological psychology, Duquesne University Press, Pittsburgh, CA.

Heath, S.B., 1983, Ways with words: Language, life, and work in communities and classrooms, Cambridge University Press, Cambridge.

Henderson, R. \& Hirst, E., 2006, 'How sufficient is academic literacy? Re-examining a short course for "disadvantaged" tertiary students', paper presented at the
Australian Association for Research in Education Annual conference 2006: Engaging Pedagogies, Adelaide, South Australia, 27-30th November 2006. 
Henderson, R. \& Hirst, E., 2007, 'Reframing academic literacy: Re-examining a shortcourse for "disadvantaged" tertiary student', English Teaching: Practice and Critique (6)2, 25-38.

Irvine, M., 2009, 'An in-service ECD career path at Rhodes University, South Africa from "school leaving" certificate to post graduate level', paper presented at the 4th African International ECD conference, Dakar, Senegal, November 2009.

Johns, A.M., 1997, Text, role and context: Developing academic literacies, Cambridge University Press, Cambridge.

Lea, M.R. \& Street, B.V., 1998, 'Students' writing in higher education: An academic literacy approach', Studies in Higher Education 23(2), 157-172. https://doi.org/ 10.1080/03075079812331380364

Lea, M.R. \& Street, B.V., 2000, 'Student writing and staff feedback in higher education: An academic literacies approach', in M.R. Lea \& B. Stierer (eds.), Students writing in higher education: New contexts, pp. 32-46, The Society for Research into Higher Education and Open University Press, Buckingham.

Lillis, T. \& Scott, M., 2007, 'Defining academic literacies research: Issues of epistemology, ideology and strategy', Journal of Applied Linguistics 4(1), 5-32. https://doi.org/ 10.1558/japl.v4i1.5

McKenna, S., 2004, 'Lecturers' discourse about the interplay between language and learning', South African Journal of Higher Education 18(2), 278-286. https://doi. org/10.4314/sajhe.v18i2.25468

McKenna, S., 2012, 'The context of access and foundation provisioning in South Africa', in R. Dunpath \& R. Vithal (eds.), Access and success in higher education, pp. 50-60, Pearson, Cape Town.

Morrow, W., 2009, Bounds of democracy: Epistemological access in higher education, HSRC Press, Cape Town.
Neil, M. \& Shashi, N., 2016, 'Embedding academic literacies in university programme curricula: A case study', Studies in Higher Education, 41 (7), 1-17.

Northedge, A., 2003, 'Rethinking teaching in the context of diversity', Teaching in Higher Education 8(1), 17-32. https://doi.org/10.1080/1356251032000052302

Pym, J., 2013, 'From fixing to possibility: Changing a learning model for undergraduate students', South African Journal of Higher Education 27(2), 353-367. https://doi. org/10.1080/03075079.2011.582096

Richards, K. \& Pilcher, N., 2016, 'Academic literacies: The word is not enough', Teaching in Higher Education 23(2), 162-177. https://doi.org/10.1080/13562517.2017.1360270

SAQA (South African Qualifications Authority), 2007, 'The uptake and impact of qualifications and unit standards in the sub-field: Early Childhood Development', SAQA report, SAQA, Pretoria.

Scollon, R. \& Scollon, S.B.K., 1981, Narrative, literacy and face in interethnic communication, Abalex Publishing Company, Norwood, NJ.

Street, B., 1984, Literacy in theory and practice, Cambridge University Press, Cambridge.

Street, B., 1996, 'Academic literacies', in D. Baker, J. Clay \& C. Fox (eds.), Challenging ways of knowing, pp. 109-138, Falmer Press, London.

Street, B., 2006, Autonomous and ideological models of literacy: Approaches from new literacy studies, viewed 12 November 2012, from http://www.philbu.net/ media-anthropology/street_newliteracy.pdf.

Walton, R., Bowman, E. \& Osman, B., 2015, 'Promoting access to higher education in an unequal society', South African Journal of Higher Education 29(1), 262-269.

Yeasmin, S. \& Rahman, K.F., 2012, "'Triangulation" research method as the tool of social science research', BUP Journal 1(1), 154-163. 